\title{
Analysis of the Influence of Support During Measurement Using Coordinate Measuring Techniques
}

\author{
Roman Michalski', Michał Wieczorowski', Przemysław Glazowski, Bartosz Gapiński \\ 1 Poznan University of Technology, Institute of Mechanical Technology, Department of Metrology and \\ Measurement Systems, ul. Jana Pawła II 24, 60-965 Poznań, Poland \\ 2 State Higher Vocational School in Kalisz, ul. Nowy Świat 4, 62-800 Kalisz, Poland \\ * Corresponding author's e-mail: przemyslaw.glazowski@dmgmori.com
}

\begin{abstract}
The article presents the analysis of the influence of various fixtures of the Y-axis slide of the CMX 70U machining center measured in a coordinate measuring machine. As a result of a series of measurements of the designated geometric features, specific deviations were determined, and statistical calculations were performed on their basis. The further part of the article shows the analysis of the theoretical body deflection under the influence of the force of gravity performed using the MES method in CREO Simulate.
\end{abstract}

Keywords: coordinate measuring machine, CMM, MES, fulcrum, mounting for measurement, statistical analysis, machining center.

\section{INTRODUCTION}

The coordinate measuring technique is currently one of the most universal measuring methods $[12,13]$. It is widely used both in the inspection of produced elements and in highly specialized research centers. That stems mostly from a very small measuring uncertainty accompanying this process.

A very important factor in measurements conducted using the coordinate technique, significantly impacting the final results, are measurement errors and their sources. Figure 1 shows which error sources, dependent not only on the machine, affect the measurement result. The sources of errors were divided into five groups. They include: the measuring machine, the environment, that is the external factors, the qualities of the measured material, the operator skills, and the often omitted measurement strategy, of which a component is the method of mounting the measured element $[16,15,21]$.

The mounting method of the measured parts influences not only the quality of the results but also the duration of the measurement. In general, the mounting method should be determined by the objective of the measurement. In the case of individual measurements, standard tools can be used, such as a vise or a vee block. In the case of a serial production or the measurements of the elements with a great freedom of shape, it is necessary to use specialized apparatus allowing for a quick and repeatable mounting of the parts [6].

\section{TYPES OF FIXTURES}

The mounting system is a solution for positioning, immobilizing, and supporting the object during measurement.

As it was mentioned in the introduction, mounting the element for measurement is very important for the efficiency and precision of the control process. An important component of designing a mounting system is the optimal distribution of the support elements to minimize the deformation of the object by the clamping force and the force of gravity. 

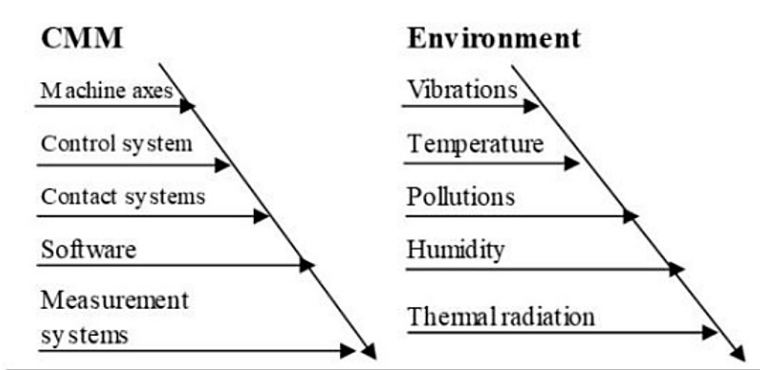

\section{Meas ured object}

Mass

Elasticity

Tolerance value

Microstructure

Surface roughness

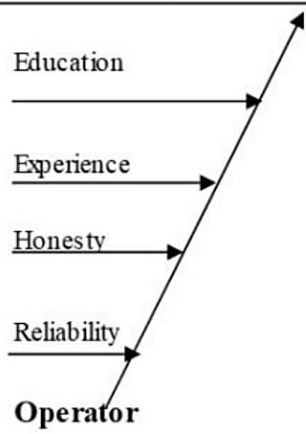

Distribution of measuring points

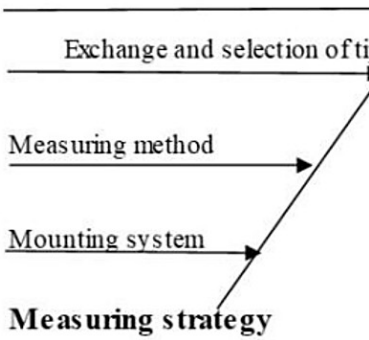

Fig. 1. Sources of errors in the coordinate measuring technique [3]

Although the literature on fixtures is quite vast regarding the mounting objects for processing in a machine tool $[3,4,5,9,10,11,14,17,23]$, there are relatively few articles regarding the mounting body elements of machine tools on coordinate measuring machines. In particular, the topic of optimal support point selection is rarely discussed; however, it is important and has a significant influence on the obtained measurement result. The literature lacks e.g. formalized rules used in the mounting body elements for measurement in a CMM.

Fastening the parts to be measured on the coordinate measuring machine differs from in- stalling the parts for processing. The measured elements must be fixed in such a way as to prevent any, even minimal displacement of the body during measurements. The forces introduced by the measuring process (measuring head) are very low; therefore, the mounting systems used in the CMM measurement do not have to be as massive and limiting as the mounting systems used in machine tools. Nonetheless, it should be noted that measurement uncertainties obtained in the coordinate measuring machines are often by an order of magnitude smaller than the dimensional tolerances [18, 19, 21].

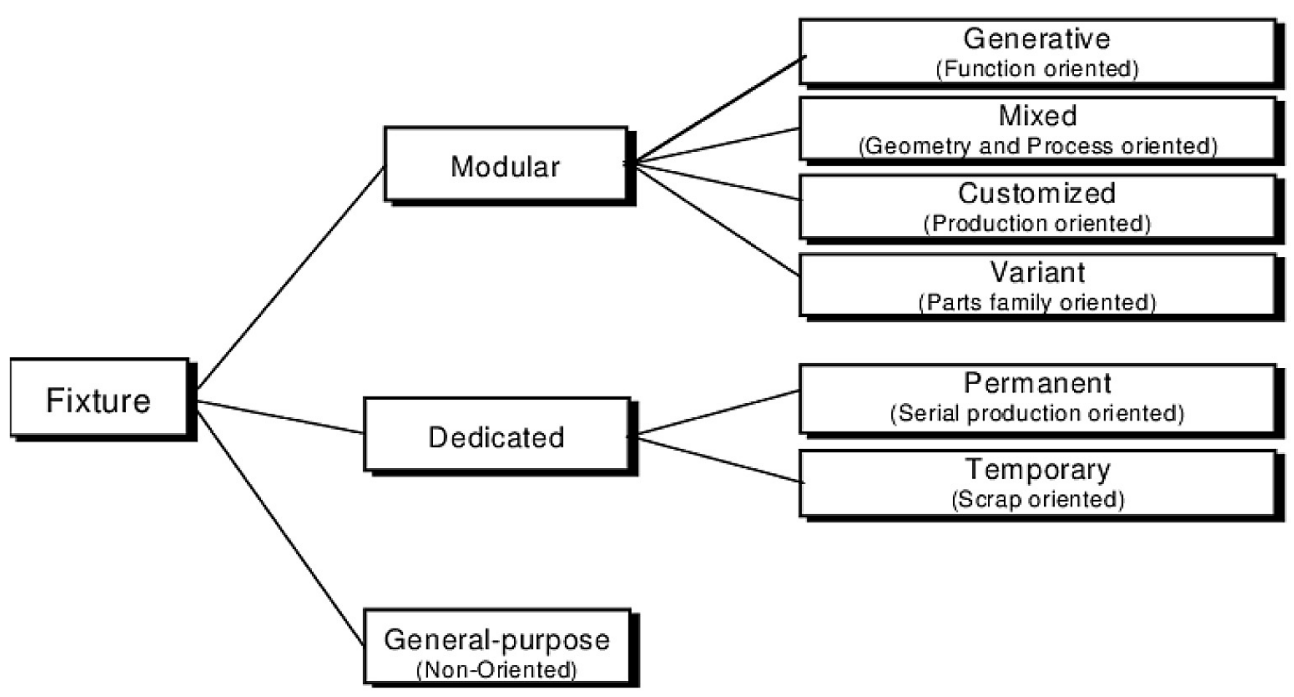

Fig. 2. Taxonomy of fixtures [7] 
The diagram below presents the general classification of the fixtures used in the industry. In the case of a CMM, the most commonly used are modular (automotive, mass production) and general purpose (low volume and individual production) fixtures. The dedicated fixtures most often found in the in-line solutions in mass production are least common. Modular fixtures increase their market share due to their flexibility and affordable price. Currently, every CMM manufacturer offers this type of solution [24].

The most commonly used modular solutions include adjustable base plates (Fig. 3), flat, semispherical, and pressure bearing elements, universal elements, self-centering and matrix type selfcentering elements (Fig. 4).

\section{DESCRIPTION OF THE TEST STAND AND THE SUBJECT OF THE STUDY}

The goal of the study was determining the mounting method of the Y-axis slide of the CMX

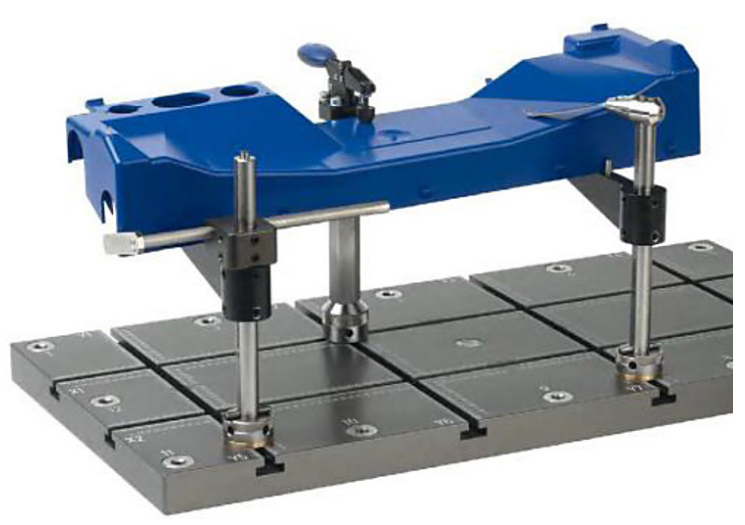

Fig. 3. Adjustable plate with support elements [7]

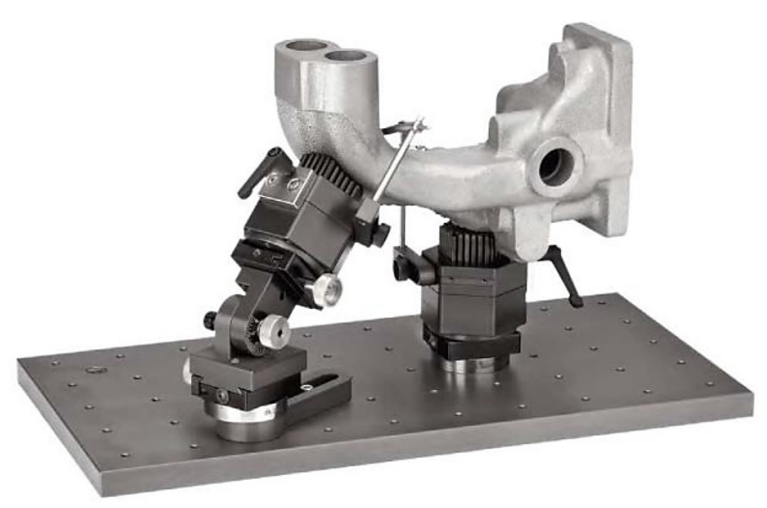

Fig. 4. Matrix type fixture [22]
70U machining center using three different fixtures (support distribution) for measurement in the coordinate measuring machine. The tests were carried out using a Zeiss Accura II 10 aktiv portal coordinate measuring machine, located in the measurement laboratory of the FAMOT PLESZEW company, shown in Figure 5. It is a coordinate machine with an immobile table with the X, Y, Z measuring range of $1200 \mathrm{~mm}$ $/ 2400 \mathrm{~mm} / 1000 \mathrm{~mm}$. Electronic drive control was used in each axis, and the sliding force was additionally limited in the $\mathrm{X}$ and $\mathrm{Z}$ axes [16]. The machine is equipped with a VAST GOLD scanning measuring head, measuring rulers made of glass ceramics with a resolution of $0.04 \mu \mathrm{m}$, integrated vibration dampening system, and correction of the temperature of the measured part. The ma-

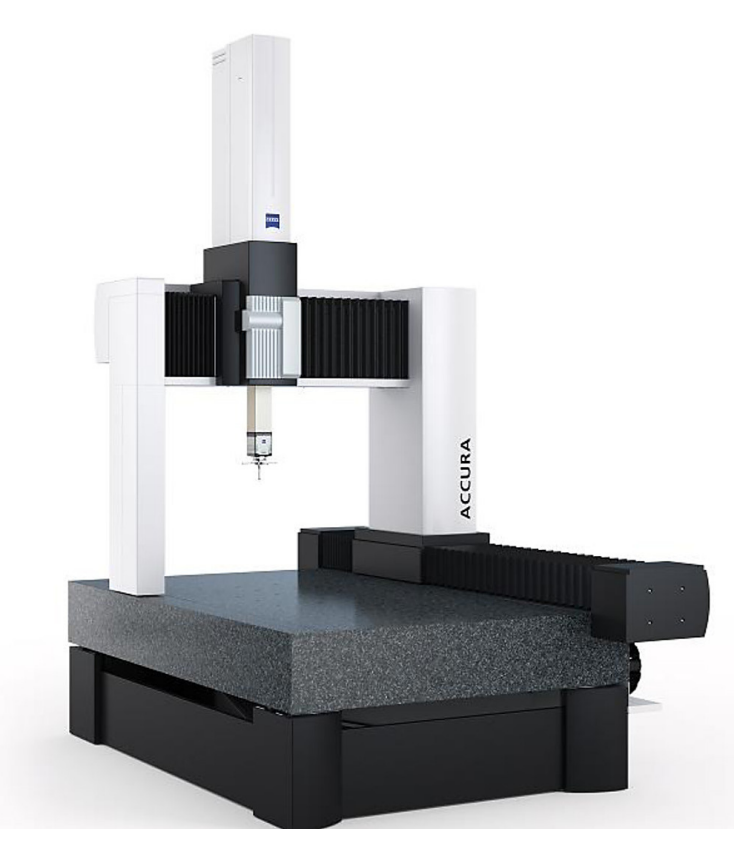

Fig. 5. Zeiss Accura coordinate measuring machine

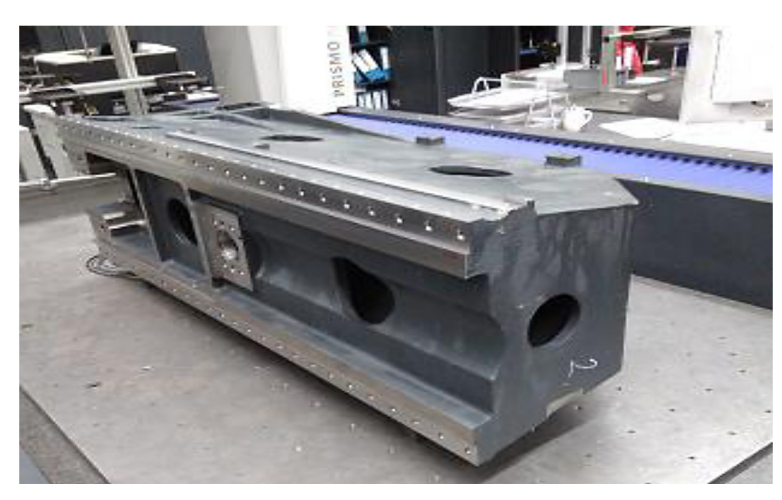

Fig. 6. Y-axis slide of CMX 70U on the CMM table 


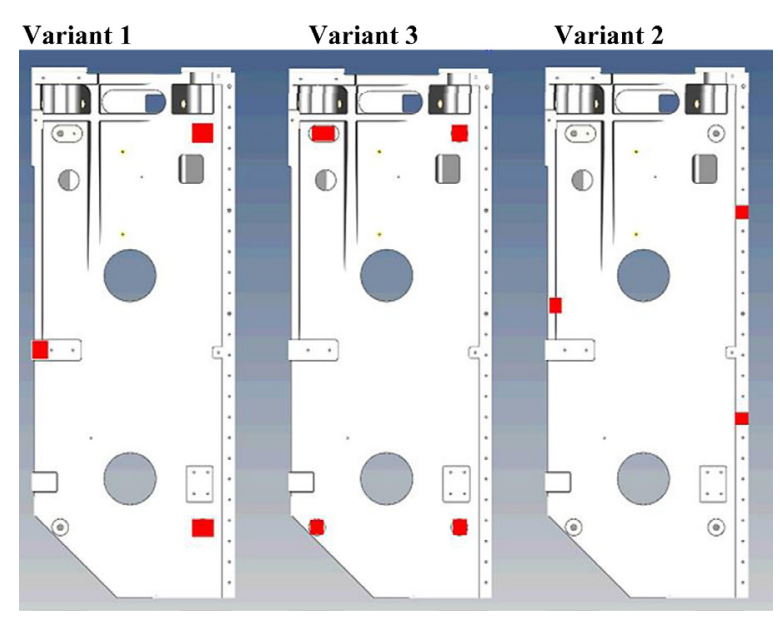

Fig. 7. Different types of fixtures for the Y-axis slides for measurement in a CMM

chine has been prepared for work in accordance with the reverification procedure [15].

The subject of the research was the Y-axis slide of the CMX 70U universal machining center in the number of 30 units, the overall appearance of which is shown in Figure 6.

The tested slide, being a body type element, was placed on a CMM table using a stable threepoint fixture (two variants) and a four-point fixture, ensuring the absence of any stress.

\section{MEASUREMENT CYCLE}

The measurements were carried out using a modified program for the measurement of serial parts at the FAMOT company. The measurement methodology and the used gauge plunger were analogous to those used in serial measurements. 30 slides were measured in three different fixtures. A total of 90 measurements were made, 510 geometric features were measured. The screen with the measuring program is presented in Figure 8.

Each subsequent measurement cycle consisted of the following actions:

1. Preparing the part for measurement.

2. Calibration of gauge plungers.

3. Mounting the body for measurement on the CMM table (3-point fixture variant 1).

4. Manual orientation of the part.

5. Starting the $\mathrm{CNC}$ cycle.

6. Analysis of the obtained results.

7. Saving the results as a PDF file and in the ASCI format for further analysis.

8. Dismounting the body from the CMM.

9. Mounting the part for measurement again (3-point fixture variant 2).

10. Manual orientation of the part.

11. Starting the CNC cycle.

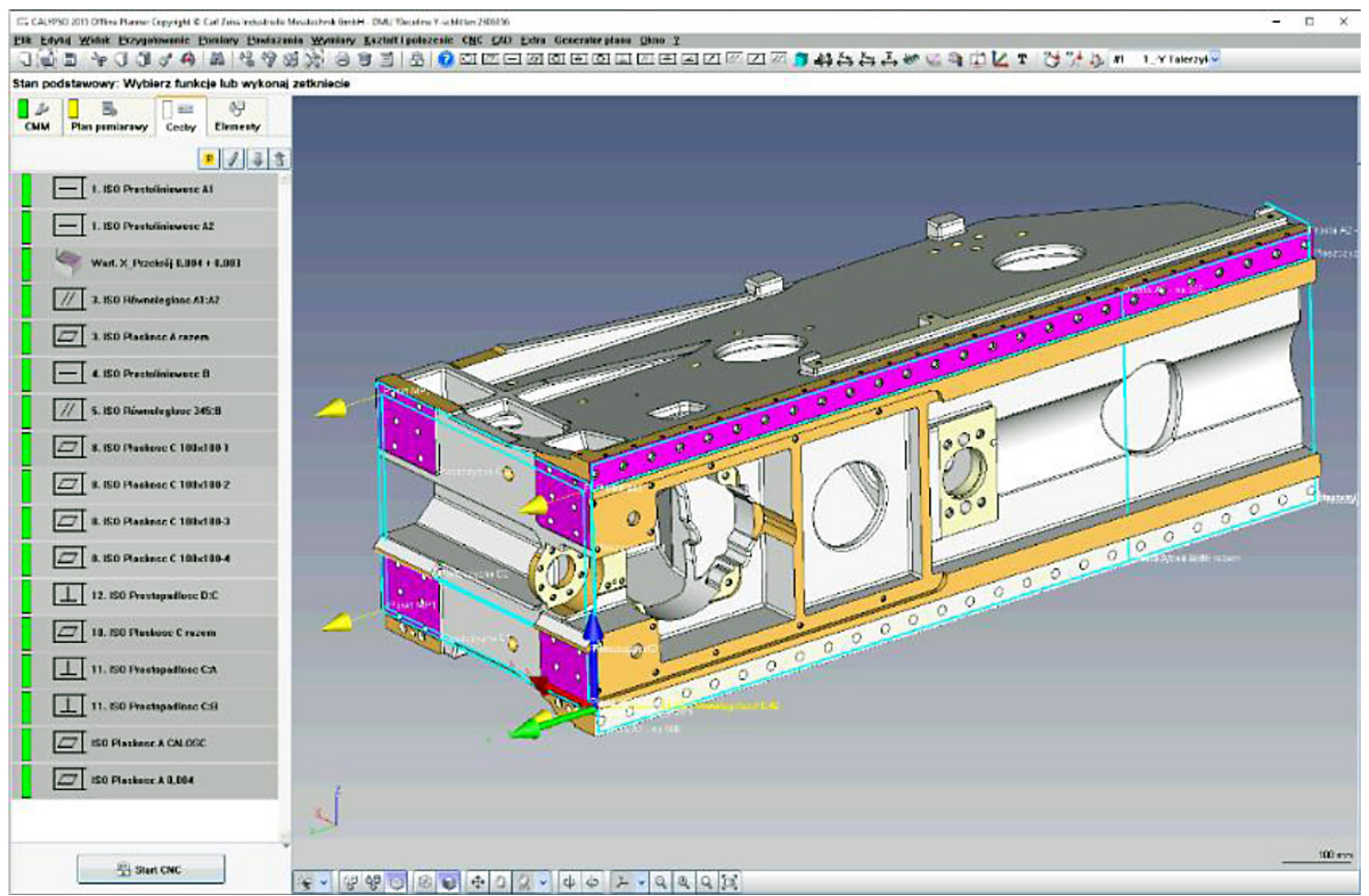

Fig. 8. Measuring program in the Calypso Offline Planner environment 
12. Saving the results as a PDF file and in the ASCI format for further analysis.

13. Dismounting the body from the CMM.

14. Fixing the part for measurement again (4-point fixture).

15. Manual orientation of the part.

16. Starting the $\mathrm{CNC}$ cycle, etc.

During the conducted measurements, the geometrical features in table 1 were measured [2].

\section{MEASUREMENT RESULTS}

The series of measurements of the Y-axis slide in different fixtures (variant $1,2,3$ ) yielded the specific measurement results, obtained on the basis of which statistical calculations were carried out in Statistica. Tables 2, 3, 4 present the results of the statistical calculations.

Table 1. Measured geometrical features

\begin{tabular}{|c|c|c|c|}
\hline Ordinal number & Deviation & Tolerance [mm] & Position in drawing \\
\hline 1 & rectilinearity & 0.003 & 1 \\
\hline 2 & rectilinearity & 0.003 & 1 \\
\hline 3 & 0.004 & 0.003 & 4 \\
\hline 4 & rectilinearity & 0.005 & 5 \\
\hline 5 & parallelism & 0.005 & 8 \\
\hline 6 & flatness & 0.005 & 11 \\
\hline 7 & perpendicularity & 0.005 & 11 \\
\hline 8 & perpendicularity & 0.005 & \\
\hline
\end{tabular}

Table 2. Statistical calculations for the 3-point fixture (variant1)

\begin{tabular}{|c|c|c|c|c|c|c|c|c|c|c|c|c|}
\hline $\begin{array}{c}\begin{array}{c}\text { Position in } \\
\text { drawing }\end{array} \\
\end{array}$ & \begin{tabular}{|l}
$\begin{array}{l}\text { Checked } \\
\text { parameter }\end{array}$ \\
\end{tabular} & $\begin{array}{c}\text { Tole rance } \\
\text { [mm] }\end{array}$ & Size & Mean & Median & Modal & Modal size & Min. & Max. & Variation & $\begin{array}{r}\text { Standard } \\
\text { deviation }\end{array}$ & Skewness \\
\hline 1 & c & 0,01 & \multirow{6}{*}{30} & 0,004270 & 0,004300 & Wielokr. & 3 & 0,002800 & 0,006200 & 0,000000 & 0,000672 & 0,362037 \\
\hline 4 & u & 0,01 & & 0,002447 & 0,002400 & Wielokr. & 3 & 0,001200 & 0,003700 & 0,000000 & 0,000674 & 0,084810 \\
\hline 7 & c & 0,01 & & 0,005293 & 0,005150 & Wielokr. & 3 & 0,003200 & 0,009500 & 0,000002 & 0,001392 & 0,907440 \\
\hline 9 & $f$ & 0,01 & & 0,008050 & 0,008000 & . & 3 & 0,004200 & 0,013000 & 0,000005 & 0,002194 & 0,229107 \\
\hline 11 & u & 0,01 & & 0,002537 & 0,002550 & . 0027000 & 4 & 0,001700 & 0,003400 & 0,000000 & 0,000433 & $-0,049862$ \\
\hline 12 & b & 0,01 & & 0,009367 & 0,007100 & . 0028000 & 3 & 0,002500 & 0,030200 & 0,000053 & 0,007298 & 1,444936 \\
\hline
\end{tabular}

Table 3. Statistical calculations for the 3-point fixture (variant 3)

\begin{tabular}{|c|c|c|c|c|c|c|c|c|c|c|c|c|}
\hline $\begin{array}{c}\text { Position in } \\
\text { drawing }\end{array}$ & $\begin{array}{l}\text { Checked } \\
\text { parameter }\end{array}$ & $\begin{array}{c}\text { Tole rance } \\
{[\mathrm{mm}]}\end{array}$ & Size & Mean & Median & Modal & Modal size & Min. & Max. & Variation & $\begin{array}{l}\text { Standard } \\
\text { deviation }\end{array}$ & Skewness \\
\hline 1 & c & 0,01 & \multirow{6}{*}{30} & 0,004417 & 0,004500 & Wielokr. & 3 & 0,002600 & 0,006100 & 0,000001 & 0,000830 & $-0,309565$ \\
\hline 4 & $\mathbf{u}$ & 0,01 & & 0,002363 & 0,002300 & Wielokr. & 3 & 0,001000 & 0,003900 & 0,000000 & 0,000704 & 0,104788 \\
\hline 7 & c & 0,01 & & 0,005687 & 0,005600 & .0058000 & 4 & 0,003100 & 0,009800 & 0,000002 & 0,001401 & 0,831296 \\
\hline 9 & $f$ & 0,01 & & 0,008953 & 0,009000 & .0106000 & 3 & 0,004100 & 0,015100 & 0,000006 & 0,002424 & 0,569357 \\
\hline 11 & $\mathbf{u}$ & 0,01 & & 0,002507 & 0,002500 & .0026000 & 6 & 0,001800 & 0,003300 & 0,000000 & 0,000418 & 0,421322 \\
\hline 12 & b & 0,01 & & 0,009140 & 0,007350 & Wielokr. & 2 & 0,002100 & 0,029000 & 0,000050 & 0,007061 & 1,567851 \\
\hline
\end{tabular}

Table 4. Statistical calculations for the 4-point fixture (variant 2)

\begin{tabular}{|c|c|c|c|c|c|c|c|c|c|c|c|c|}
\hline $\begin{array}{c}\text { Position in } \\
\text { drawing }\end{array}$ & \begin{tabular}{|l|} 
Checked \\
parameter
\end{tabular} & $\begin{array}{c}\text { Tolerance } \\
{[\mathrm{mm}]}\end{array}$ & Size & Mean & Median & Modal & Modal size & Min. & Max. & Variation & $\begin{array}{l}\text { Standard } \\
\text { deviation }\end{array}$ & Skewness \\
\hline 1 & C & 0,01 & \multirow{6}{*}{30} & 0,004260 & 0,004100 & .0041000 & 5 & 0,002900 & 0,007000 & 0,000001 & 0,001033 & 1,308233 \\
\hline 4 & $\mathbf{u}$ & 0,01 & & 0,002800 & 0,002550 & .0030000 & 3 & 0,001100 & 0,013500 & 0,000005 & 0,002143 & 4,527567 \\
\hline 7 & c & 0,01 & & 0,005487 & 0,005450 & .0049000 & 3 & 0,003700 & 0,009400 & 0,000001 & 0,001156 & 1,200030 \\
\hline 9 & $f$ & 0,01 & & 0,008890 & 0,008600 & Wielokr. & 2 & 0,004100 & 0,016800 & 0,000008 & 0,002813 & 0,851390 \\
\hline 11 & $\mathbf{u}$ & 0,01 & & 0,002560 & 0,002600 & .0026000 & 7 & 0,001800 & 0,003200 & 0,000000 & 0,000361 & $-0,171255$ \\
\hline 12 & b & 0,01 & & 0,009230 & 0,007550 & .0078000 & 2 & 0,001900 & 0,028100 & 0,000047 & 0,006887 & 1,543857 \\
\hline
\end{tabular}




\section{FEM ANALYSIS}

The next stage of the study involved performing the FEM analysis for three different support variants of mounting the body for the measurement.

The purpose of the analysis was to determine the impact of fixing stress on the body and to check the correlation of measurement results with the FEM calculations. The research on the impact of support points on the results of the Y-axis slide of the CMX 70U was carried out using the CMM Zeiss Accura.

The details of the measured geometrical parameters are provided in the following points:

1. position 1 - rectilinearity $0.003 \mathrm{~mm}$ at the 986 $\mathrm{mm}$ section of the faying surface of the linear guide rails (surface $\mathrm{A}$ ).

2. linear dimension $0.004 \mathrm{~mm}+/-0.003 \mathrm{~mm}$ orientation of the final section of surface A.

3. position 4 - rectilinearity $0.003 \mathrm{~mm}$ of the abutment surface of the linear guide rails (surface $B$ ).

4. position 5 - parallelism $0.005 \mathrm{~mm}$ of abutment surfaces of the right and left linear guide rails.

5. position 8 - flatness $0.005 \mathrm{~mm}$ of two mounting surfaces of $\mathrm{Z}$-axis linear guide rails carriage (surface $\mathrm{C}$ ) .

6. position $11-$ perpendicularity $0.005 \mathrm{~mm}$ of surface $\mathrm{C}$ to base $\mathrm{A}$.

7. position 11 - perpendicularity $0,005 \mathrm{~mm}$ of surface $\mathrm{C}$ to base $\mathrm{B}$.

The analysis of theoretical body deflection under the influence of the force of gravity performed using the FEM method [1] in CREO Simulate.
During the FEM analysis, the following boundary conditions have been assumed:

- material EN-GJL 300,

- fixture points - in accordance with the diagram in figure 7 ,

- load - force of gravity.

The program simulated the theoretical deflection of the casting body under the influence of gravity during the mounting of the body for measurement at specific support points.

After the analysis of the results, the following conclusions can be formulated:

1) for the 3-point support (variant 1) currently used for measurement, the maximum value of the linear displacement for the body was $0.0042 \mathrm{~mm}$ in the casting window area (deviation insignificant from the perspective of static geometry of the body). The value of the linear displacement of the measured surfaces ranged from 0.00086 to $0.00384 \mathrm{~mm}$.

2) for the 3-point modified support (variant 3), the maximal value of the linear displacement for the body is $0.00594 \mathrm{~mm}$ in the C surface area. The value of the linear displacements in the remaining measured areas ranged from 0.0016 to $0.00594 \mathrm{~mm}$.

3) for the 4-point support (variant 2), the maximal value of the linear displacement for the body reached $0.00598 \mathrm{~mm}$ again in the casting window area (deviation insignificant from the perspective of static geometry of the body). The value of the linear displacement of the measured surfaces ranged from 0.000003 to $0.00417 \mathrm{~mm}$.

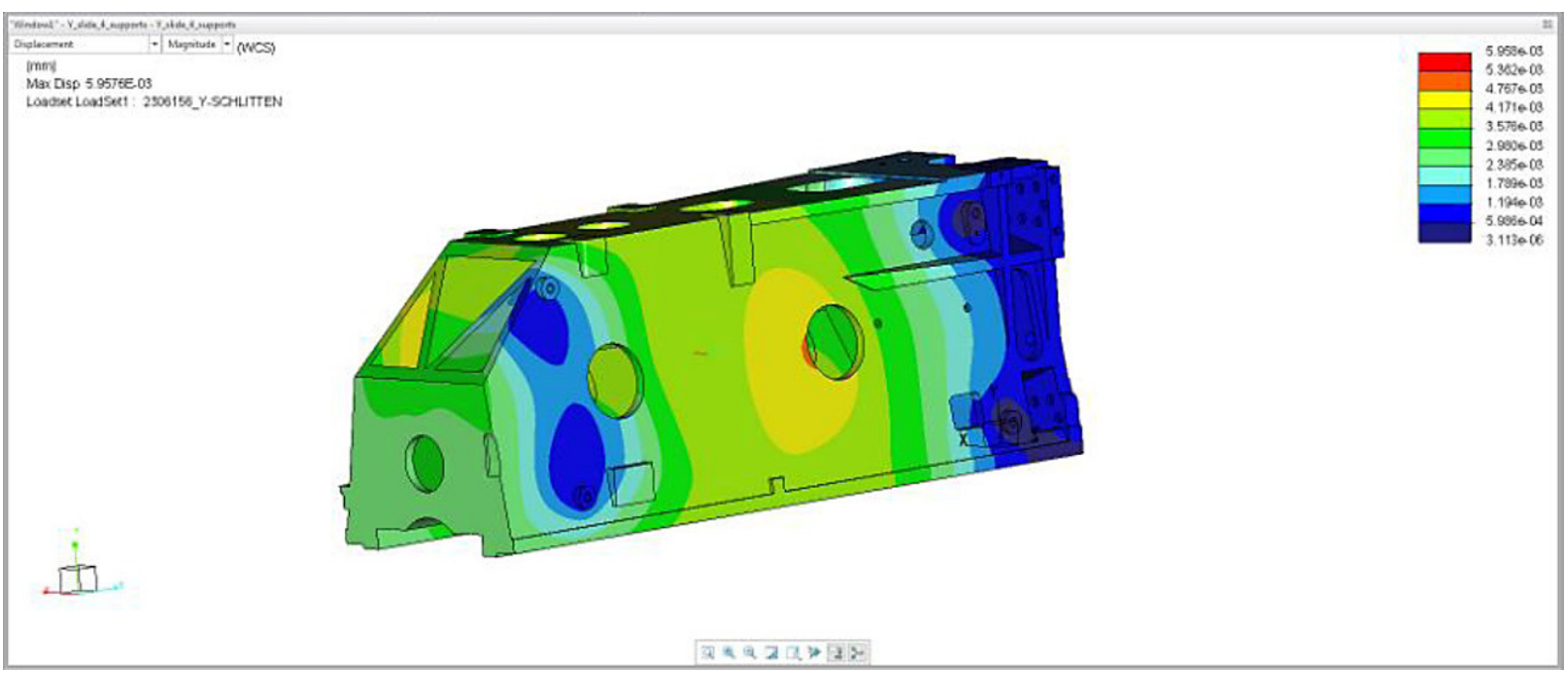

Fig. 9. An example of the FEM visualization for the 4-point support (variant 2) 


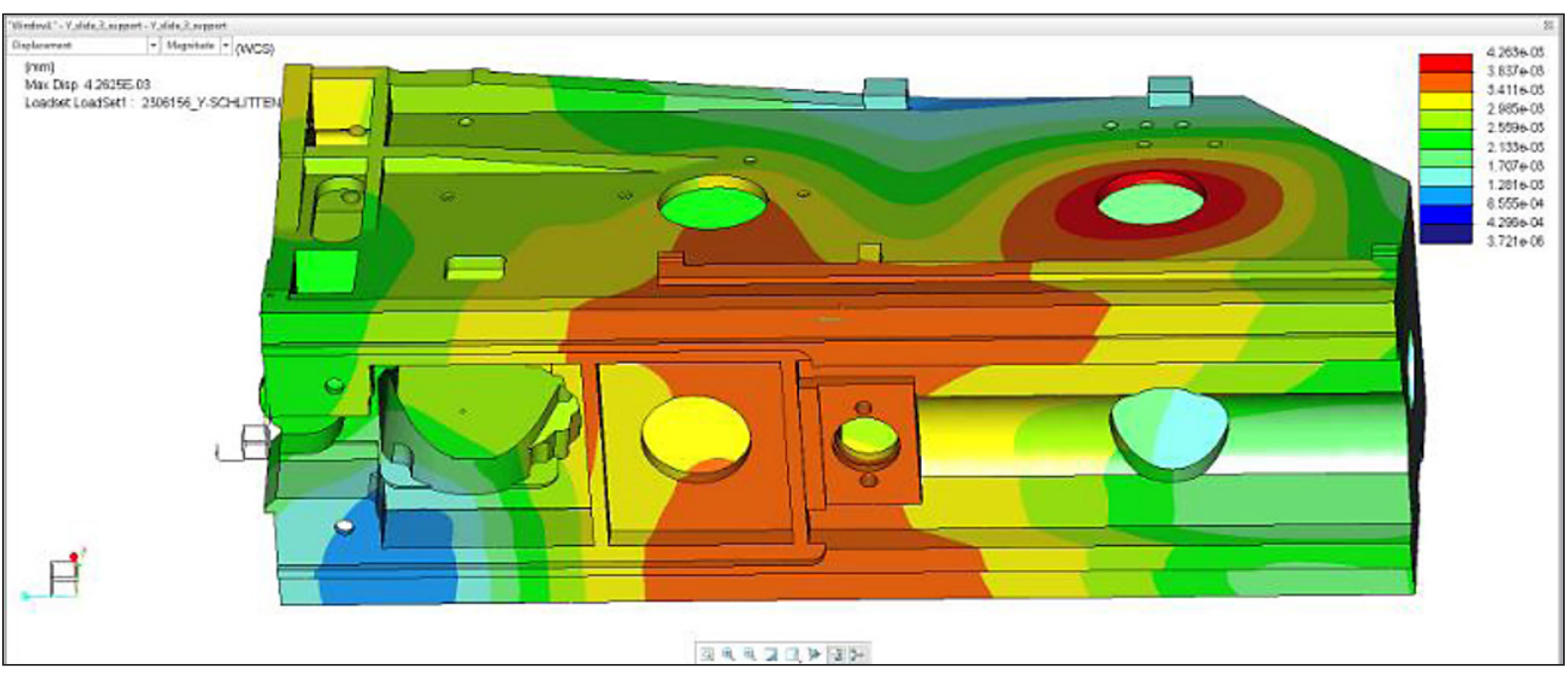

Fig. 10. An example of the FEM visualization for the 3-point support (variant 1)

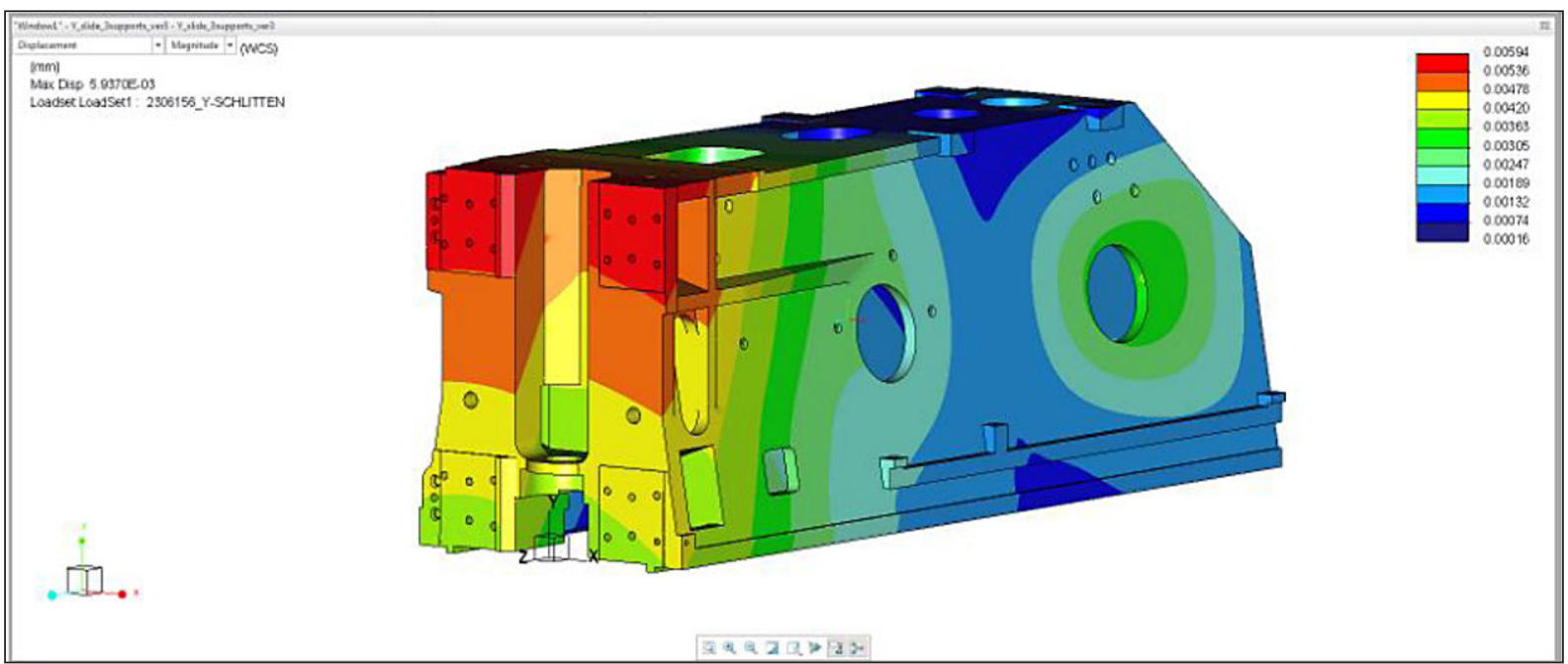

Fig. 11. An example of the FEM visualization for the 3-point support (variant 3)

\section{CONCLUSIONS}

As a result of the FEM analysis, it can be hypothesized that the three-point fixture for mounting the body for measurements used so far causes the smallest deflection, although its value, i.e. $0.00384 \mathrm{~mm}$, is significant enough in the relation to the tolerance field assumed by the constructor to require compensation by the appropriately directed machining or another form of eliminating the problem to be considered, e.g. conducting subsequent FEM analyses using different support points for the body for measurement, determining the points that will allow attaching the element to be measured in a way that minimizes or eliminates the body deformation.
Four-point support causes a deflection of $0.00043 \mathrm{~mm}$, but it is more evenly distributed. This type of support is an alternative to the currently used solution. The modified three-point support is rejected due to the introduction of the largest deflection in the areas particularly important for the static geometry of the measured body.

The method of supporting the body for measurement is not without significance for the obtained final result of the measured geometrical features. The measurements show that in the case of the modified three-point support for the body, for the condition of rectilinearity (Position in drawing no. 4) the result differs by $0.0017 \mathrm{~mm}$, and for the condition of parallelism (Position in drawing No. 5) - by $0.00138 \mathrm{~mm}$. These differences in mea- 
surements with an assumed tolerance of $0.005 \mathrm{~mm}$ can affect not only the stability and repeatability of the measurement process, but also of machining.

The conducted study may indicate the direction of the technologists working with machining processes. In addition to using any programs supporting the machining processes, it is recommended to use the FEM analysis, because it offers an opportunity to analyze the deflection of the body at the stage of preparation of the machining processes [8]. Despite requiring some effort, the analysis can bring many benefits, e.g. eliminating corrections, reducing the number of non-compliant parts, etc.

A common practice in coordinate metrology in the industry is the adaptation of the machining fixtures for the measuring purposes, which is justified due to the cost reduction and the lack of introducing additional variables in the form of other fixtures or support points. Greater attention is paid to the stability of the fixture; the issues of the introduced stresses are pushed into the background. Therefore, from the metrological point of view, the study is also important because it indicates the direction of development of the field, which involves the optimal support points for body elements for measurement in a CMM.

\section{REFERENCES}

1. Balonek K., Gozdur S., Wprowadzenie do Metody Elementu Skończonego. AGH, 1999.

2. Białas S., Humienny Z., Kiszka K., Metrologia z podstawami specyfikacji geometrii wyrobów (GPS). Oficyna Wydawnicza Politechniki Warszawskiej, Warszawa 2014.

3. Barylski A., Konstrukcja i montaż obróbkowych uchwytów modułowych. Technika Transportu Szynowego, 12(12) 2017, 238-241.

4. Bekiesza M., Analiza opłacalności stosowania uchwytów modułowych w operacjach technologicznych. WM PG, 2017.

5. Bi Z.M., Zhang W., J., Flexible fixture and automation: Review, issues and future directions. International Journal of Production Research 39(13), 2001, 2867-2894.

6. Carl Zeiss company informational material, https:// www.zeiss.pl, access: 29.05.2019.

7. Consalter L.A., Boehs L., An approach to fixture systems management in machining processes. Journal of the Brazilian Society of Mechanical Sciences and Engineering, 26(2), 2004, 145-149.

8. Dębkowski R., Ostrowski P., Analiza MES wpływu wielkości oraz rozkładu sił mocow- ania na dokładność obróbki przedmiotu o małej sztywności. Mechanik, 8-9, 2014, 289-296.

9. DeMeter. E. C., Fast support layout optimization. International Journal of Machine Tools and Manufacture, 38(10), 1998, 1221-1239.

10. Feld M., Uchwyty obróbkowe, WNT, 2002.

11. Gaoliang P., Gongdong W., Wenjian L., Haiquan Y., A Desktop virtual reality-based interactive modular fixture configuration design system. Computer-Aided Design, 42(5), 2010, 432-444.

12. Gapiński B., Wieczorowski M., Grzelka M., Arroyo Alonso P., Bermúdez Tomé A., The application of micro CT to assess quality of workpieces manufactured by means of rapid prototyping. Polimery, 62(01), 2017, 53-59.

13. Gapinski B., Wieczorowski M., Marciniak-Podsadna L., Dybala B., Ziolkowski G., Comparison of Different Methods of Measurement Geometry Using CMM, Optical Scanner and Computed Tomography 3D. Procedia Engineering, 69, 2014, 255-262.

14. Karpiuk M., Sieczka K., Głaz K., Biblioteka 3D CAD modeli elementów uniwersalnych przyrządów składanych. Mechanik, 91(1), 2018, 64-66.

15. Koteras R., Wieczorowski M., Znaniecki P., Acceptance and reverification of CMM in industrial conditions. Advances in Science and Technology Research Journal, 12(1), 2018, 80-88.

16. Matuszewski M., Dokładność i błędy pomiarowe we współrzędnościowej technice pomiarowej. Magazyn Przemysłowy, 2018.

17. Menassa R., De Vries W., Optimization methods applied to selecting support positions in fixture design. ASME J. of Engineering for Industry, 113(4), 1991, 412-418.

18. Ratajczyk E., Współrzędnościowa technika pomiarowa. Oficyna Wydawnicza Politechniki Warszawskiej, 2005.

19. Ratajczyk E., Woźniak A., Współrzędnościowe systemy pomiarowe. Oficyna Wydawnicza Politechniki Warszawskiej, 2016.

20. Roithmeier R., Pruefgerechte Tolerierung Maß, Form und Lage. Eine Publikation der Zeiss Metrology Academy, 2017.

21. Sładek J., Dokładność pomiarów współrzędnościowych. Wydawnictwo Politechniki Krakowskiej, 2011.

22. Spannfix company informational material, https:// www.spannfix.de, access 30.05.2019.

23. Vallapuzha S., De Meter E., Shabbir C., Raghunath P. K., An investigation of the effectiveness of fixture layout optimization methods. International Journal of Machine Tools and Manufacture, 42(2), 2002, 251-263.

24. Wenzel company informational material. Fixturing: An Important Part of CMM Accuracy. Wenzel Americ, 2015. 